удК 343.98

\author{
B. Ю. Шепітько
}

\title{
ПРОБЛЕМИ ТИПІЗАЦІЇ ОКРЕМИХ КРИМІНАЛІСТИЧНИХ МЕТОДИК
}

Постановка проблеми. Нинішній стан розвитку криміналістики в Україні характеризується формуванням загальної теорії криміналістики, розробкою і впровадженням сучасних науково-технічних засобів та інформаційних технологій у практику протидії злочинності, вдосконаленням прийомів криміналістичної тактики, пропонуванням методик розслідування нових видів злочинів. Певні тенденції властиві синтезуючому розділу криміналістики - криміналістичній методиці (поєднанню криміналістичної техніки і тактики щодо видової своєрідності злочинів). Специфічним сьогодні $€$ захоплення розробкою різних видів криміналістичних методик (комплексних, видових, підвидових, позавидових та ін.). Однак їхній зміст, структурна побудова, елементний склад потребують певної уніфікації.

Виклад основного матеріалу дослідження. У прагматичному сенсі криміналістична методика складається з упорядкованого комплексу порад типізованого характеру - окремих методик (методичних рекомендацій), що $є$ найбільш ефективними під час розслідування різних видів злочинів. А.В. Шмонін справедливо зауважує, що результати пошуку нових підходів до побудови структури криміналістики перебувають у безпосередньому зв'язку з розумінням структури та змісту методики розслідування злочинів (окремих криміналістичних методик) [1]. М.П. Яблоков підкреслює, що методика розслідування є певною системою, у якій акумулюються узагальнені дані слідчої практики, положення низки криміналістичних теорій, дані криміналістичної техніки і тактики, окремі положення інших наук із метою розроблення методів розслідування окремих видів злочинів [2]. B.M. Терехович указує, що криміналістична методика систематизовано описує процес отримання певним чином структурованого справжнього знання, необхідного і достатнього для кримінально-правової оцінки розслідуваної події [3].

Окрема криміналістична методика - це система взаємопов'язаних і взаємозумовлених дій. Її завданням є розроблення типових систем (алгоритмів) дій слідчого, що сприяють обранню оптимальної поведінки у процесі розслідування певного виду злочинів. Така методика має містити типові 
комплекси слідчих (розшукових) та інших дій або заходів, передбачає певну послідовність їх реалізації.

Окремі криміналістичні методики мають виконувати певні функції. У спеціальних джерелах виокремлюють такі іiі функції: 1) описово-інформаційну; 2) пізнавально-прагматичну; 3) прогностично-евристичну; 4) дидактичну (навчальну) [4]. У цьому сенсі суттєву роль має відігравати саме пізнавально-прогностична функція окремої криміналістичної методики сприяння оптимальному розслідуванню певного виду злочинів, оскільки окрема криміналістична методика - це певна модель, «певний шаблон, розслідування здійснюється за схемою, використовується метод аналогії [5]. В.В. Тіщенко вказує, що до сучасних методик розслідування усе частіше зараховують програми розслідування, спрощується викладення матеріалу, який пояснюється. Річ у тім, що значна кількість теоретичного матеріалу, докладне викладення дискусійних поглядів, їхній критичний аналіз утруднюють сприйняття практиком пропонованих методичних і тактичних рекомендацій, робить методику з погляду слідчого малоефективною для практичного використання [6].

Нині дискусійною проблемою є визначення внутрішнього змісту окремої криміналістичної методики, їі структурних елементів. Останнім часом під час формування окремих криміналістичних методик, яке відбувається, як правило, у процесі написання дисертаційного дослідження, до структурних елементів зараховують криміналістичну характеристику певного виду злочинів, початковий етап розслідування, тактику проведення слідчих (розшукових) дій. На нашу думку, такий підхід вирішує лише «дисертаційну функцію» або описово-інформаційну. Оскільки побудова практичної конструкції передбачає виявлення кореляційних залежностей між елементами криміналістичної характеристики злочинів завдяки узагальненню значного масиву кримінальних проваджень (справ), встановленню ефективності проведення окремих слідчих (розшукових) дій та їх оптимального поєднання і послідовності у вигляді тактичних операцій, визначення певної стадійності (етапності) досудового розслідування не обмежене лише початком (початковим етапом) розслідування.

Формування окремих криміналістичних методик має бути розраховано на конкретного адресата - слідчого (сторону кримінального провадження). Тому від описового підходу до окремих криміналістичних методик необхідно переходити до певної стандартизації та уніфікації. Тому досить важливими є пропозиції щодо розроблення Реєстру окремих криміналістичних методик [7]. У криміналістичних джерелах досить докладно було запропоновано порядок формування і функціонування такого реєстру. Висловлювалися пропозиції щодо його доцільності й ефективності [8].

Прагнення перебудувати всю слідчу діяльність передбачає одержання відповідей на такі запитання: хто є суб’єктом цієї діяльності, які органи можуть їі здійснювати, які засоби можна залучати та на якому етапі? Слідча діяльність за своєю природою є пізнавальною. У процесі цієї діяльності вирішуються розумові завдання, що сприяють оперативному одержанню 
інформації про злочин і злочинця. У цьому сенсі може бути поставлене й питання про те, на якого суб'єкта має бути розрахована окрема криміналістична методика: на слідчого, його процесуального керівника, начальника слідчого підрозділу, слідчого суддю. Окрім того, можна говорити й про необхідність забезпечення науковими методичними порадами (рекомендаціями) й іншу сторону кримінального провадження - сторону захисту.

У зв'язку з демократизацією кримінального процесу, прагненням впровадити змагальний процес до стадії досудового провадження пропонується переглянути функціональне призначення слідчого й обмежити його лише обвинувальною функцією, створити формулу «слідчий - обвинувач», тобто він виконує діяльність сторони обвинувачення. Така позиція чітко простежується й у КПК України. Відповідно до глави 3 КПК України слідчого органу досудового розслідування (ст. 40) уже віднесено до сторони обвинувачення.

У змагальному процесі важливим $є$ розмежування функцій учасників на функції обвинувачення, захисту та вирішення справи за сутністю. На досудовому слідстві таку схему або конструкцію важко визнати ідеальною. Доцільно відзначити існування і такої функції, як функція розслідування злочинів. Інакше слідчі завжди будуть виявляти обвинувальний ухил. 3 іншого боку, складно уявити рівність сторін на досудовій стадії провадження у справі. Виходить, що у такому разі слідчий буде збирати лише докази обвинувачення, а захисник - докази захисту шляхом так званого «паралельного розслідування». Тоді мають створюватись окремі криміналістичні методики для сторони обвинувачення і для сторони захисту.

У сучасній криміналістиці мають місце погляди щодо необхідності розроблення окремих криміналістичних методик для прокурора або для суду. Так, О.С. Рубіс зазначає, що невід’ємною частиною процесуального керівництва розслідуванням із боку прокурора $є$ давання вказівок суб'єктам доказування про побудову загальної криміналістичної моделі діяльності 3 доказування фактів вчинення злочину і злочинної поведінки винуватих у його вчиненні осіб [9]. I.I. Когутич пише, що варто констатувати, що існує потреба в обгрунтуванні принципової можливості і необхідності застосування криміналістичних знань у такій сфері кримінального судочинства, як розгляд кримінальних справ у суді першої інстанції, у подальшій розробці тактики та започаткуванні методики їх судового розгляду щодо окремих категорій злочинів [10]. Методика судового розгляду кримінальних справ як підсистема криміналістичної методики (поряд із методикою розслідування окремих видів, груп злочинів) розпочинає своє функціонування 3 моменту надходження кримінальної справи в суд і до прийняття у ній судом відповідного рішення. У ній досліджуються та містяться відповіді на інші, аніж у методиці розслідування окремих видів, груп злочинів, запитання: як планувати судовий розгляд кримінальної справи; яка сутність судових ситуацій, які виникають, і чим вони відрізняються від слідчих ситуацій; які методичні прийоми необхідно використати для вирішення проблемних ситуацій в умовах змагального процесу, що і як необхідно встановити, в якій послідовності; яким є алгоритм дій суду, державного 
обвинувача та захисника тощо [11]. В.К. Гавло підкреслює, що традиційна структура криміналістичної методики розслідування має бути доповнена й іншими складниками. Як її складники слід виокремити три взаємопов'язані блоки: 1) криміналістична характеристика скоєння окремих видів і груп злочинів; 2) криміналістична характеристика розкриття, розслідування і запобігання окремим видам і групам злочинів на попередньому (досудовому) розслідуванні; 3) криміналістична характеристика судового розгляду окремих видів і груп злочинів [12].

Структура окремої криміналістичної методики має охоплювати такі важливі структурні елементи: криміналістична характеристика певного виду злочинів, предмет розслідування, типові слідчі ситуації і типові версії на початку розслідування, система слідчих (розшукових) дій на початку розслідування, система слідчих (розшукових) дій під час подальшого розслідування, типові тактичні операції, система заходів щодо нейтралізації протидії розслідуванню, профілактичні дії слідчого.

У структурі окремої криміналістичної методики важливе місце має посісти такий іï елемент, як типові тактичні операції. Тактична операція - це поєднання однойменних або різнойменних слідчих (розшукових) дій, негласних слідчих (розшукових) дій, оперативно-розшукових, організаційних заходів, спрямованих на виконання проміжного завдання розслідування у певній слідчій ситуації. Типова тактична операція - це алгоритм, програма дій слідчого, оперативного працівника, інших осіб щодо завдань, які виникають, і слідчих ситуацій [13]. Побудова і використання тактичних операцій $€$ визначальною тенденцією розвитку слідчої практики з метою вирішення завдань, які інакше вирішити складно або взагалі неможливо [14].

Типові тактичні операції завжди звернені до майбутнього, характеризуються певним прогностичним моментом. У визначенні ролі тактичних операцій деякі вчені-криміналісти справедливо вважають, що вони повинні розроблятись у контексті формування відповідної видової або підвидової методики (мікрометодики), тобто вони мають бути їх невід'ємною складовою частиною. Крім того, вони повинні бути максимально «прив'язані» до типових слідчих ситуацій і виходити із конкретних тактичних завдань, що стоять перед слідчим [15].

Заслуговують на увагу підходи деяких учених-криміналістів, які виокремлюють стратегічне в розслідуванні злочинів, намагаються обгрунтувати існування криміналістичної стратегії. Зокрема, М.П. Яблоков пише, що важливе місце посідають питання стратегії діяльності під час розроблення багатопланових питань методики розслідування. Тому необхідне чітке визначення у ній стратегічних завдань, що стоять перед розслідуванням, ii головних тактичних завдань загалом, окремих етапів розслідування, а також вибір оптимальних тактичних операцій і слідчих дій для вирішення вказаних завдань [16]. В.А. Журавель зазначає, що можливість розподілу завдань розслідування на стратегічні й тактичні зумовлює необхідність диференціації засобів їх вирішення, оскільки між завданнями та засобами їх розв'язання існує логічний зв'язок. Оптимальний вибір слідчих дій i 
оптимальна послідовність їх провадження є головними принципами формування і функціонування інформаційно-пізнавальної моделі окремої криміналістичної методики розслідування злочинів. При цьому типові системи слідчих дій, відображені в методиці розслідування, зумовлені предметом доказування у кримінальній справі, правовими цілями розслідування, а також типовими слідчими ситуаціями [17]. Таким чином, формування i пропонування типових тактичних операцій певним чином співвідноситься із постановленням та вирішенням стратегічних (перспективних) завдань.

Побудова окремих методик розслідування злочинів залежить від різних чинників: виду (підвиду, групи) злочинів, предмета доказування у кримінальному провадженні, ступеня розробленості криміналістичної характеристики певного виду, можливостей ситуаційного моделювання та визначення відповідних криміналістичних засобів (слідчих (розшукових) дій, інших заходів, тактичних операцій тощо). Зокрема, слідча практика вимагає створення таких окремих криміналістичних методик, які б враховували зміст типових для кожного виду злочинів слідчих ситуацій i залежно від нього рекомендували б той чи інший варіант організації розслідування [18].

Проблеми типізації окремих криміналістичних методик пов'язані з необхідністю алгоритмізації слідчої діяльності. Алгоритмізація розслідування певним чином співвідноситься $з$ його тактичним та методичним забезпеченням. Тому важливим для економії процесуальних засобів $€$ надання усіх необхідних відомостей у вигляді бази знань, створеної за правилами побудови алгоритмів. Прикладом реалізації такої бази знань $є$ розроблене нами Автоматизоване робоче місце слідчого «Інсайт», що відповідає сучасним потребам слідчої практики. Одним із блоків такого робочого місця є система «Криміналістичні методики» (методика розслідування злочинів) [19].

Висновки. Процес розслідування злочинів у деяких випадках пов'язаний із дослідженням складної злочинної діяльності, декількох взаємопов'язаних поміж собою злочинних актів. Така діяльність передбачає використання комплексних криміналістичних методик і запровадження слідчих технологій. При цьому в криміналістиці категорія «слідча технологія» є досить новою. Ії сутність належним чином не досліджувалась. Хоча, на нашу думку, саме слідчі технології мають бути найбільш перспективним і ефективним криміналістичним знаряддям у розслідуванні складних злочинів або злочинної діяльності. Існує думка, що така технологія визначає оптимальний рух кримінального провадження (справи) під час розслідування злочину, послідовність виконання слідчих (розшукових) дій або організаційно-технічних заходів, систему використовуваних криміналістичних засобів та їх режим. Слідча технологія - це певний процес, послідовність реалізації слідчої діяльності, застосування криміналістичних засобів (прийомів, способів, рекомендацій, операцій) під час розслідування окремого виду (підвиду) злочинів, спрямований на досягнення істини у справі. Застосування слідчої технології дає змогу оптимально виконувати дії під час розслідування злочинів [20]. Сьогодні взагалі можна відзначити тенденцію 
щодо технологізації процесу розслідування, судового розгляду, провадження судової експертизи. Зокрема, може йтися про запровадження високих технологій, IT-технологій, сучасних комп'ютерних або електронних технологій та ін. Окрім того, у деяких джерелах справедливо підкреслюється, що слідча технологія - це не усталена конструкція. Технології розслідування злочинів на практиці можуть змінюватись майже щодня за рахунок впровадження досягнень науки і техніки [21].

\section{Література}

1. Шмонин А.В. Методика расследования преступлений : [учеб. пособ.] / А.М. Шмонин. М. : Юстицинформ, 2006. - С. 399.

2. Яблоков Н.П. Криминалистическая методика расследования: история, современное состояние и проблемы : [монография] / Н.П. Яблоков. - М. : Норма: ИНФРА-М, 2016. - С. 77.

3. Терехович В.Н. Теория криминалистики. Общая часть : [монография] / В.Н. Терехович. - Рига, 2015. - С. 271.

4. Щур Б.В. Теоретичні основи формування та застосування криміналістичних методик [монографія] / Б.В. Щур. - Харків : Харків юрид., 2010. - С. 124-131.

5. Там само. - С. 127.

6. Тищенко В. Содержание и границы методик расследования преступлений / В. Тищенко / / Криміналістика та судова експертиза: наука, навчання, практика : зб. наук. праць у 2-х т. - Харків : Апостіль, 2014. - С. 479.

7. Щур Б.В. Теоретичні основи формування та застосування криміналістичних методик : [монографія] / Б.В. Щур. - Харків : Харків юрид., 2010. - С. 261-270.

8. Більш докладно див.: Щур Б.В. Система окремих криміналістичних методик та проблема їх практичного застосування / Б.В. Щур / / Правова інформатика. - 2011. - № 3-4 (31). - С. 161-167.

9. Рубис А.С. Криминалистическое обеспечение деятельности прокурора в сфере борьбы с преступностью / А.С. Рубис. - Минск : БГУ, 2005. - С. 225.

10. Когутич I.I. Криміналістичні знання, іх сутність і потреба розширення меж використання : [монографія] / I.І. Когутич. - Львів : Тріада плюс, 2008. - С. 74.

11. Когутич I.I. Використання знань та засобів криміналістичної тактики і методики під час розгляду кримінальних справ у суді : [монографія] / I.I. Когутич. - Львів : Тріада плюс, 2009. - C. $247,248$.

12. Гавло В.К. О позитивных тенденциях развития криминалистической методики как раздела науки криминалистики / В.К. Гавло / / Ситуационный подход в юридической науке и правоприменительной деятельности : матер. Междунар. науч.-практ. конф. / под ред Т.С. Волчецкой ; БФУ им. И. Канта. - Калининград : Изд-во БФУ им. И. Канта, 2012. - С. 204.

13. Шепітько В.Ю. Криміналістична тактика (системно-структурний аналіз) : [монографія] / В.Ю. Шепітько. - Харків : Харків юрид., 2007. - С. 179.

14. Аверьянова Т.В. Криминалистика : [учеб.] / Т.В. Аверьянова, Р.С. Белкин, Ю.Г. Корухов, Е.Р. Россинская ; под ред. Р.С. Белкина. - М. : НОРМА-ИНФРА-М, 1999. - С. 507.

15. Журавель В.А. Тактичні операції в системі криміналістичних засобів протидії злочинності / В.А. Журавель / / Теорія і практика судової експертизи і криміналістики. - Харків, 2006. - Вип. 6. - С. 36.

16. Яблоков Н.П. Криминалистическая методика расследования: история, современное состояние и проблемы : [монография] / Н.П. Яблоков. - М. : НОРМА-ИНФРА-М, 2016. - С. 113.

17. Журавель В.А. Обставини, що підлягають з'ясуванню у структурі криміналістичної методики / В.А. Журавель / / Теорія та практика судової експертизи і криміналістики. - Харків : Право, 2010. - Вип. 10. - С. 19.

18. Ренер Н.А. Использование ситуационного подхода при построении частных методик расследования / Н.А. Ренер / / Ситуационный подход в юридической науке и правоприменительной деятельности : матер. Междунар. науч.-практ. конф. / под ред. Т.С. Волчецкой ; БФУ им. И. Канта. - Калининград : Изд-во БФУ им. И. Канта, 2012. - С. 206.

19. Шепітько В.Ю. Проблеми алгоритмізації слідчої діяльності / В.Ю. Шепітько, Г.К. Авдєєва / / Актуальні проблеми держави і права. - Одеса : Юрид. лит-ра, 2008. - Вип. 44. - С. 46-50. 
20. Див.: Криміналістика : [підруч.] / [В.Ю. Шепітько, В.О. Коновалова, В.А. Журавель та ін.] ; за ред. В.Ю. Шепітька. - 5-те вид. переробл. і доп. - К. : Ін Юре, 2016. - С. 419, 420.

21. Малярова В.О. Теоретичні основи формування методики розслідування злочинів проти моральності у сфері статевих стосунків / В.О. Малярова // Науковий вісник Львівського державного університету внутрішніх справ. - 2013. - Вип. 4. - С. 380.

\section{А нот а ці я}

Шепітько В. Ю. Проблеми типізації окремих криміналістичних методик. - Стаття. Статтю присвячено проблемам формування та типізації окремих криміналістичних методик, визначенню їх змісту і структурних складників. Акцентовано увагу на необхідності застосування уніфікованих підходів до окремих криміналістичних методик та створення їх реєстру. Розроблення окремих криміналістичних методик має бути спрямовано на різних учасників та стадії кримінального провадження у змагальному процесі. Відстоюється позиція про доцільність віднесення до структури окремої криміналістичної методики типових тактичних операцій, які певним чином співвідносяться із постановленням та вирішенням стратегічних (перспективних) завдань. Оптимальність застосування окремих криміналістичних методик пов'язано із технологізацією процесу розслідування та судового розгляду.

Ключові слова: окрема криміналістична методика, криміналістична методика, типова тактична операція, розслідування злочинів, судовий розгляд, алгоритмізація розслідування.

\section{Анн о т а ци я}

\section{Шепитько В. Ю. Проблемы типизации отдельных криминалистических методик. - Статья.}

Статья посвящена проблемам формирования и типизации отдельных криминалистических методик, определению их содержания и структурных составляющих. Акцентировано внимание на необходимости применения унифицированных подходов к отдельным криминалистическим методикам и создания их реестра. Разработка отдельных криминалистических методик должна быть направлена на различных участников и стадии уголовного производства в состязательном процессе. Отстаивается позиция о целесообразности отнесения к структуре частной криминалистической методики типичных тактических операций, которые определенным образом соотносятся с постановлением и решением стратегических (перспективных) задач. Оптимальность применения отдельных криминалистических методик связана с технологизацией процесса расследования и судебного разбирательства.

Ключевые слова: отдельная криминалистическая методика, криминалистическая методика, типичная тактическая операция, расследование преступлений, судебное разбирательство, алгоритмизация расследования.

\section{S u m m a r y}

Shepitko V. Yu. Problems of typization of certain forensic methods. - Article.

The article is devoted to the problems of forming and typification of separate criminalistic methodologies, determination of their maintenance and structural constituents. Attention is accented on the necessity of application of the compatible going near separate criminalistic methodologies and creation of their register. Development of separate criminalistic methodologies must be sent to the different participants and stages of criminal realization in a contention process. Position is defended about expedience of attributing to the structure of separate criminalistic methodology of typical tactical operations, that definitely, is correlated from setting and deciding of strategic (perspective) tasks. The optimality of application of separate criminalistic methodologies is related to technolization of process of investigation and judicial trial.

Key words: separate criminalistic methodology, criminalistic methodology, typical tactical operation, investigation of crimes, trial, algorithmization of investigation. 